J. Amer. Soc. Hort. Sci. 116(5):813-817. 1991.

\title{
Inhibition of Softening by Polyamine Application in 'Golden Delicious' and 'McIntosh' Apples
}

\author{
George F. Kramer, Chien Yi Wang, and William S. Conway \\ Horticultural Crops Quality Laboratory, Agricultural Research Service, U.S. Department of \\ Agriculture, Beltsville, MD 20705
}

Additional index words. calcium, Malus domestics, postharvest physiology, putrescine, spermidine, spermine

\begin{abstract}
Pressure infiltration of 'Golden Delicious' and 'McIntosh' apples (Malus domestica Borkh.) with polyamides resulted in an immediate increase in firmness. 'Golden Delicious' apples were $2.7 \mathrm{~N}(0.25 \mathrm{mM}$ spermidine $)$ to $6.7 \mathrm{~N}$ (1.0 mM spermine) firmer, while 'McIntosh' apples were $2.2 \mathrm{~N}(0.25 \mathrm{mM}$ spermidine) to $5.3 \mathrm{~N}$ (1.0 $\mathrm{mM}$ spermine) firmer than the water-treated control. During 28 weeks of storage at $0 \mathrm{C}$, the differences between the polyaminetreated and water-treated apples were even larger. Similar results were observed with a $3 \%$ Ca treatment, but the Ca treatment reduced the rate of softening to a greater extent than did the polyamine treatments in 'Golden Delicious'. Polyamides increased the endogenous levels of the polyamides infiltrated; however, the levels declined rapidly with time in storage. Both polyamine and $\mathrm{Ca}$ inhibited the development of chilling injury symptoms (brown core) in 'McIntosh'. The influence of polyamines on ethylene production was negligible in both cultivars. The Ca treatment, however, inhibited ethylene evolution in 'Golden Delicious'. Polyamides, thus, may affect apple softening through rigidification of cell walls rather than through interactions with ethylene metabolism.
\end{abstract}

There is increasing evidence that elevated levels of polyamides are beneficial to the maintenance of postharvest quality in fruits and vegetables. Controlled-atmosphere storage has been shown to increase polyamine levels relative to storage in air in apples (Kramer et al., 1989), zucchini (Wang and Ji, 1988), and chinese cabbage (Wang, 1988). Temperature preconditioning inhibits the development of chilling injury (CI) with concomitant increases in polyamine levels in zucchini (Kramer and Wang, 1989). The treatment of fruit after harvest with spermine (SPN) has been shown to retard softening in 'Red Delicious' apples (Wang and Kramer, 1989) and inhibit the development of CI in zucchini squash (Kramer and Wang, 1989). The reduced rate of softening of long-keeping tomato cultivars has been correlated with elevated putrescine (PUT) (Dibble et al., 1988; Saftner and Baldi, 1990).

The importance of $\mathrm{Ca}$ in maintaining the postharvest quality in apple fruit is well documented (Abbott et al., 1989; Betts and Bramlage, 1977; Stow, 1989). Like the polyamides, Ca is a polycation. Calcium appears to cross-link pectic substances in the cell wall, resulting in rigidification that is detectable immediately after treatment (Abbott et al., 1989; Stow, 1989). This binding also blocks access of degradative enzymes to the cell wall, resulting in a reduced rate of softening during storage (Conway and Sams, 1987; Sams and Conway, 1984). Although endopolygalacturonase (PG) has not been found in apple tissue, pectin methylesterase is present and is negatively affected by $\mathrm{Ca}$ infiltration into the fruit (Laufman et al., 1989). Calcium also appears to inhibit ethylene production in 'Golden Delicious' apples (Conway and Sams, 1987; Glenn et al., 1988; Sams and Conway, 1984).

As the mechanism of $\mathrm{Ca}$ action appears to involve its cationic nature, polyamides may be able to act in a similar manner. Polyamides can bind to carrot cell walls in vivo (Mariani et al., 1989; Pistocchi et al., 1987) and to pectic substances in vitro (D’Orazi and Bagni, 1987). Polyamides can also inhibit the

Received for publication 2 Oct. 1990. We express our gratitude to Frank Liu and Dave for their assistance in obtaining the apples and to Hilarine Repace and George Brown for technical assistance. The cost of publishing this paper was defrayed in part by the payment of page charges. Under postal regulations, this paper therefore must be hereby marked advertisement solely to indicate this fact. activity of PG, presumably through binding to pectic acid (Kramer et al., 1989). Metabolic interactions with ethylene are also possible, as polyamides and ethylene share common precursors and polyamides can inhibit the activity of ethylene biosynthetic enzymes (Apelbaum et al., 1981; Even-Chen et al., 1982; Suttle, 1981). The purpose of our study was to observe the effects of polyamine infiltration on the storage quality of two apple cultivars and to determine whether any beneficial effects resulted from interactions with ethylene metabolism. A secondary objective was to compare the effects of $\mathrm{Ca}$ and polyamides on fruit quality when the test was conducted on the same lot of fruit under the same experimental conditions.

\section{Materials and Methods}

'McIntosh' and 'Golden Delicious' apples were harvested from various trees at optimum commercial maturity (Blanpied, 1973). The apples were randomized and pressure infiltrated $(82.7 \mathrm{kPa})$ for 4 min with 1.0 or $10.0 \mathrm{mM}$ PUT, 0.25 or $1.0 \mathrm{mM}$ spermidine (SPD), 0.25 or $1.0 \mathrm{mM} \mathrm{SPN}$, or $3 \%$ calcium chloride $\left(\mathrm{CaCl}_{2} \cdot 2 \mathrm{H}_{2} \mathrm{O}\right)(\mathrm{w} / \mathrm{v})$ solutions. Control fruit were similarly treated with distilled water. Two-hundred fruit were used in each treatment. Following treatment, the fruit were placed on Kraft paper and allowed to dry before storage at $0 \mathrm{C}$ in multiperforated polyethylene bags. Fruit firmness was measured on a pared surface (three per fruit) with a Magness-Taylor penetrometer equipped with an 11-mm plunger (Ballauf Manufacturing Co., Laurel, Md.). Samples were taken for pressure test immediately following chemical treatments and at 2-week intervals during storage. Chemical injury and the development of brown core were also assessed every 2 weeks by visual inspection. Fruit were transferred from 0C storage to 20C monthly for measurement of ethylene production. Ethylene production was determined with a Carle gas chromatography equipped with an alumina column (Carle Instruments, Anaheim, Calif.). To measure the uptake of polyamides and $\mathrm{Ca}$ into the apple tissue, the peel and outer flesh of the fruit, to a depth of $2 \mathrm{~mm}$, were removed and discarded. The next $3 \mathrm{~mm}$ of tissue was then removed, and this layer was analyzed for polyamine and Ca content. Samples were

Abbreviations: CI, chilling injury; PG, endopolygalacturonase; PUT, putrescine; SPD, spermidine; SPN, spermine. 
frozen and stored at $-80 \mathrm{C}$ before analysis. For the determination of $\mathrm{Ca}$ concentration, dry tissue samples $(0.250 \pm 0.005$ g) were ashed at $500 \mathrm{C}$ overnight, and the residue dissolved in $5 \mathrm{ml}$ of $6 \mathrm{~N} \mathrm{HCI}$. The samples were then diluted and analyzed for $\mathrm{Ca}$ content with atomic absorption spectrophotometry. All $\mathrm{Ca}$ values are reported on a dry-weight basis. Free polyamides were analyzed via HPLC as described by Kramer and Wang (1989). This method is similar to that of Smith and Davies (1985). Each data point is the average of three independent samples. The means of the initial firmness values were compared using the Dunnett's test. Figures were prepared using SigmaPlot software (Jandel Scientific, Corte Madera, Calif.). The traces in Figs. 1, 3, and 4 are computer-generated regression lines. The error bars represent \pm SE.

\section{Results}

Effect of polyamine and Ca treatments on softening. The concentrations of polyamides were chosen based on experiments in which treatment with levels of SPD and SPN higher than $1 \mathrm{mM}$ resulted in the development of surface damage (data not shown). Significant increases in firmness were observed immediately after treatment (Table 1). 'Golden Delicious' apples were 2.7 (0.25 mM SPD) to $6.7 \mathrm{~N}(1.0 \mathrm{mM}$ SPN $)$ firmer, whereas 'McIntosh' apples were 2.2 (0.25 mM SPD) to $5.3 \mathrm{~N}$ (1.0 mM $\mathrm{SPN})$ firmer than the control. These differences became greater during storage at $0 \mathrm{C}$ for 28 weeks (Fig. 1). For instance, after 18 weeks, the differences between polyamine-treated and control fruit ranged from $8.4(1.0 \mathrm{mM}$ PUT) to $11.5 \mathrm{~N}(1.0 \mathrm{mM}$ SPD) in 'Golden Delicious' and from 7.6 (1.0 mM PUT) to 13.3 $\mathrm{N}$ (1.0 mm SPN) in 'McIntosh' (data not shown). The effectiveness of the $3 \% \mathrm{Ca}$ treatment was comparable to the most effective polyamine treatments in 'McIntosh' (data not shown), but was significantly more effective in 'Golden Delicious' (Fig. 1).

Effect of polyamine and Ca treatments on ethylene. In 'Golden Delicious', after 4 months of storage at 0C, a climacteric peak of ethylene production occurred $\approx 5$ days after transfer to $20 \mathrm{C}$ in the control and polyamine-treated fruit (Fig. 2A). The $3 \%$ $\mathrm{Ca}$ treatment, however, resulted in an inhibition of ethylene production. In 'McIntosh' apples, neither polyamine nor $\mathrm{Ca}$ treatments affected the ethylene evolution (Fig. 2B). Similar effects of polyamine and $\mathrm{Ca}$ treatments on ethylene production were observed throughout storage.

Effect of treatments on brown core. Brown-core symptoms (CI) developed in 'McIntosh' apples after 22 weeks of storage at 0 C. From-weeks 22 to $28,42 \%$ of the control apples displayed brown-core symptoms. None of the polyamine or Ca-treated apples developed this disorder.

Chemical injury. Initial experiments showed that treatment of 'Red Delicious' with high concentrations of SPD and SPN led to the development of small black spots on the skin. Such symptoms also developed in the present experiments. In 'Golden Delicious', damage was apparent after 18 weeks in the $1-\mathrm{mM}$ SPD and both SPN treatments. In 'McIntosh', the symptoms were seen after 8 weeks. No damage was seen with $0.25 \mathrm{mM}$ SPD or either PUT treatment.

Effect of treatments on endogenous polyamine levels. The level of the polyamides used in treated 'Golden Delicious' was initially much higher than the control, followed by a rapid decline during storage (Fig. 3). The 1-mM SPD treatment also led to increase: in PUT (2- to 4-fold during weeks 2 to 8 ) and in SPN (4- to 5-fold during weeks 2 to 10). Treatment with $1 \mathrm{mM}$ SPN led to increased SPD (1.5-to 3-fold during weeks 6 to 10$)$ and PUT (1.5- to 2.5-fold during weeks 2 to 10 ). The results from the flesh tissue were similar, except that the initial SPD value in the fruit treated with $1 \mathrm{mM}$ SPD appeared to be the same as for the control (Fig. 4). These concentrations, however, increased during storage and were significantly higher (1.5- to 4-fold) than in the control after week 2. The 1-mM SPD treatment also resulted in increases in PUT (2- to 4-fold during weeks 2 to 12) and in SPN (2- to 8-fold during weeks 2 to 12). The $1 \mathrm{mM}$ SPN treatment increased the flesh SPD (1.5- to 3fold during weeks 2 to 12) and PUT (2- to 3-fold during weeks 2 to 10) content. The $\mathrm{Ca}$ treatment also appeared to result in increases in the SPD (2- to 4-fold during weeks 2 to 10) and SPN (2- to 9-fold during weeks 2 to 10). Similar results were seen in 'McIntosh', except that lesser amounts of the polyamine solutions were taken up by them than by 'Golden Delicious' (data not shown). This observation was also reflected by the amount of $\mathrm{Ca}$ found in the 3\% Ca-treated apples (Table 2).

\section{Discussion}

We have shown that pressure infiltration of apples with polyamides resulted in an immediate increase in firmness and reduced the rate of softening during subsequent storage at $0 \mathrm{C}$. Similar observations have been reported for $\mathrm{Ca}$ infiltration (Abbott et al., 1989; Stow, 1989). The mechanism of Ca action appears to involve ionic cross-linking of pectic substances in the cell wall, resulting in immediate rigidification of the wall (Conway et al., 1988; Conway and Sams, 1983). Given the charge (polycationic) and functional [ionic binding to pectic substances (D`Orazi and Bagni, 1987) and PG-inhibiting (Kra-

Table 1. Firmness of apples immediately after harvest and after pressure infiltration with polyamides or Ca.

\begin{tabular}{|c|c|c|c|c|c|c|}
\hline \multirow[b]{2}{*}{ Compound concn } & \multicolumn{3}{|c|}{ Golden Delicious } & \multicolumn{3}{|c|}{ McIntosh } \\
\hline & $\begin{array}{c}\text { Firmness } \\
(\mathrm{N})\end{array}$ & SE & $\mathrm{P}$ & $\begin{array}{c}\text { Firmness } \\
(\mathrm{N})\end{array}$ & SE & $\mathrm{P}$ \\
\hline Water & 69.8 & 0.98 & --- & 71.2 & 0.98 & --- \\
\hline \multicolumn{7}{|l|}{ PUT } \\
\hline $1.0 \mathrm{mM}$ & 73.8 & 1.07 & $<0.05$ & 73.4 & 0.98 & NS \\
\hline $10.0 \mathrm{mM}$ & 73.8 & 0.93 & $<0.05$ & 76.1 & 0.98 & $<0.01$ \\
\hline \multicolumn{7}{|l|}{ SPD } \\
\hline $0.25 \mathrm{mM}$ & 72.5 & 0.98 & $<0.05$ & 73.4 & 0.98 & NS \\
\hline $1.0 \mathrm{mM}$ & 73.4 & 0.71 & $<0.01$ & 73.4 & 0.93 & $<0.05$ \\
\hline \multicolumn{7}{|l|}{ SPN } \\
\hline $0.25 \mathrm{mM}$ & 75.2 & 1.20 & $<0.01$ & 75.2 & 0.62 & $<0.01$ \\
\hline $1.0 \mathrm{mM}$ & 76.5 & 0.67 & $<0.01$ & 76.5 & 0.89 & $<0.01$ \\
\hline $\mathrm{Ca} 3 \%$ & 73.8 & 0.85 & $<0.05$ & 76.5 & 1.33 & $<0.01$ \\
\hline
\end{tabular}




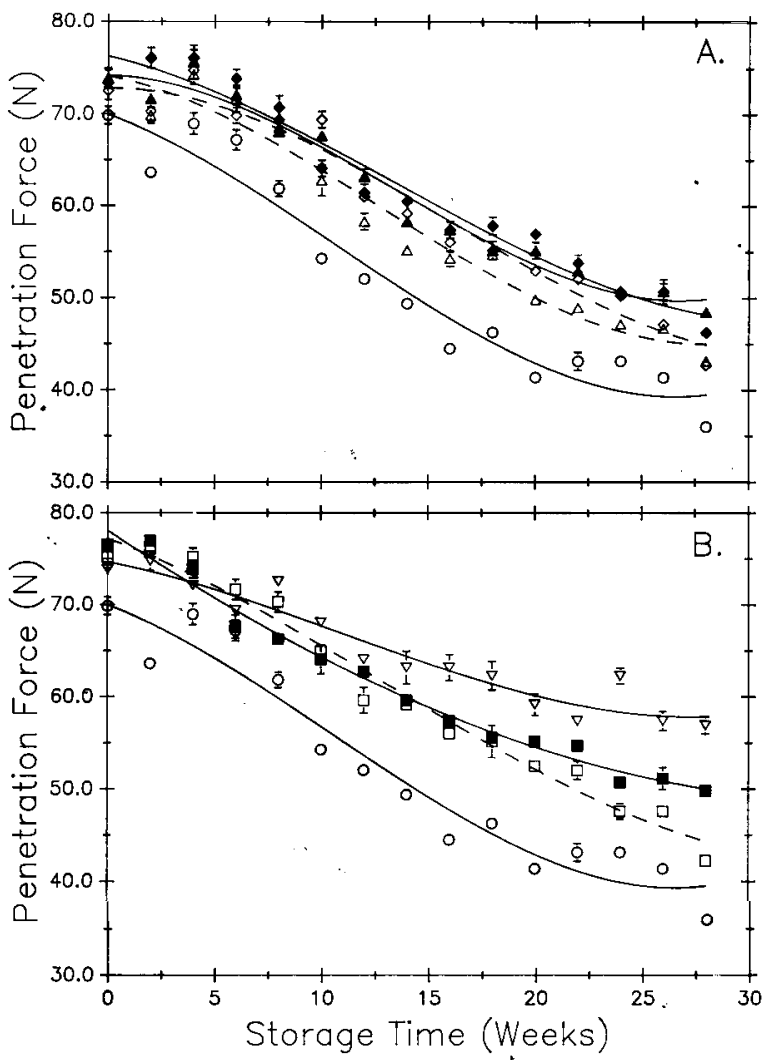

Fig. 1. Effect of PUT, SPD, and SPN on firmness of 'Golden Delicious' apples during storage at 0C. (A) Control (०-O), $1 \mathrm{mM}$ PUT $(\triangle--\Delta), 10 \mathrm{~mm}$ PUT $(\Delta-\Delta), 0.25 \mathrm{~mm}$ SPD $(\diamond-\diamond \diamond), 1 \mathrm{~mm}$ SPD

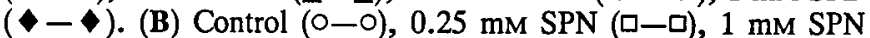
(一) $\mathbf{\square}), 3 \% \mathrm{Ca}(\nabla-\nabla)$.

mer et al., 1989)] similarities between $\mathrm{Ca}$ and polyamides, these compounds could have comparable effects. A study of 'Golden Delicious' apples (Wallace et al., 1962) revealed that as fruits mature, there is an exchange of monocations for polycations, particularly $\mathrm{Ca}$. As a result, the pectic substances in the cell wall are less extensively cross-linked and become more susceptible to decay. In other studies (Bramlage et al., 1985; Faust and Shear, 1968), Ca was found to be more important than $\mathrm{Mg}$, $\mathrm{K}, \mathrm{N}$, and $\mathrm{P}$ in influencing apple quality. In a study to determine the effect of infiltrating $\mathrm{Ca}, \mathrm{Mg}$, or strontium ( $\mathrm{Sr}$ ) into 'Golden Delicious' apples at harvest, Ca was the optimum cation for reducing decay, maintaining fruit firmness, and suppressing ethylene production (Conway and Sams, 1987). Ca infiltration has also been shown to inhibit the activity of the cell-wall-degrading enzyme pectin methylesterase in apple tissue (Laufmann et al., 1989). As polyamides are polycations, they may play a role similar to $\mathrm{Ca}$ in maintaining fruit quality. Since polycations stabilize the cell wall to a greater extent than do monocations, polyamides may either make the cell wall less accessible to wallsoftening enzymes or, in apple fruit, stabilize the cell wall to a greater extent than would a monocation. The observation that controlled-atmosphere storage results in increased levels of polyamides concomitant with a reduced rate of softening in 'McIntosh' apples supports this possibility (Kramer et al., 1989).

Although the ionic binding of polyamides and $\mathrm{Ca}$ to cell walls and membranes appears to affect biological processes, differences in the details of such effects could differ, as $\mathrm{Ca}$ and polyamides are structurally dissimilar. For instance, $\mathrm{Ca}$ and SPN both inhibit ethylene biosynthesis in apple disks, but differences

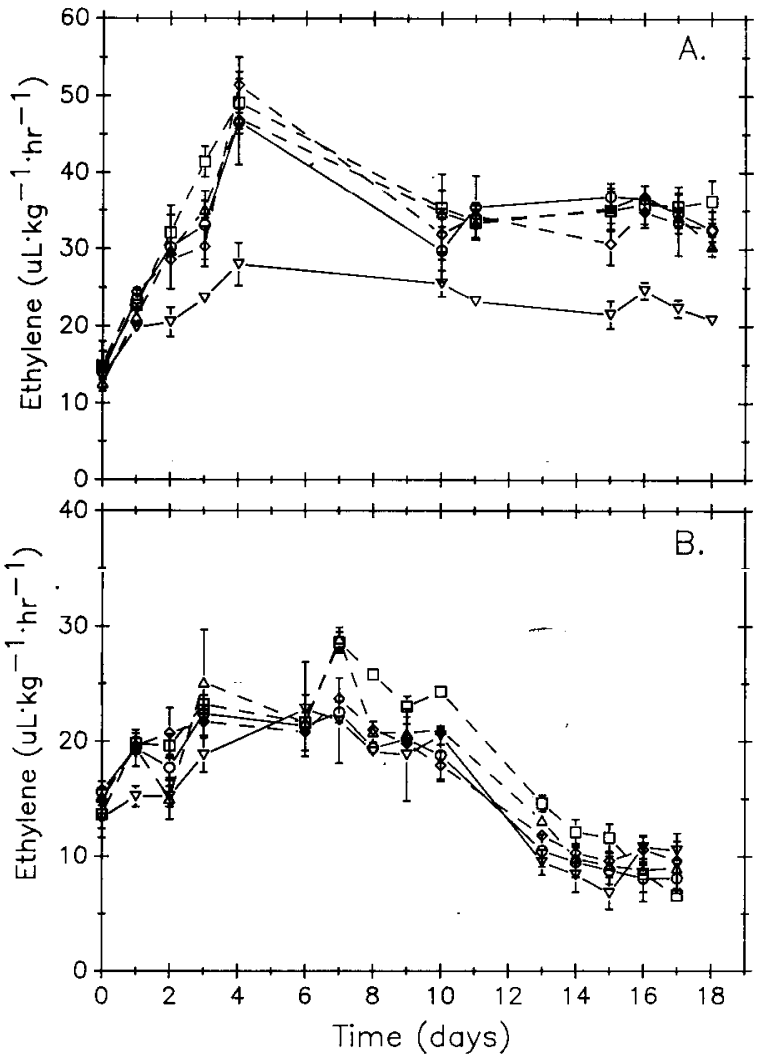

Fig. 2. Ethylene production of apples at $20 \mathrm{C}$ after removal fro1 storage. (A) 'Golden Delicious' apples after 12 weeks of storage : $0 \mathrm{C}$, as affected by polyamine and Ca treatments. Control (O-O), mM PUT $(\triangle---\Delta), 0.25 \mathrm{~mm}$ SPD $(\diamond--\diamond), 0.25 \mathrm{~mm}$ SPN (口---口) $3 \% \mathrm{Ca}(\nabla-\nabla)$. (B) 'McIntosh' apples after 16 weeks of storage : 0C. Control $(0-0), 1 \mathrm{mM}$ PUT $(\triangle--\triangle), 0.25 \mathrm{~mm}$ SPD $(\diamond--\diamond$. $0.25 \mathrm{~mm}$ SPN (----口), 3\% Ca $(\nabla-\nabla)$.

between the two compounds were observed in the effect of temperature and in the kinetics of inhibition (Ben-Arie et al., 1982). In our results, we see that $\mathrm{Ca}$ and polyamine applications have similar effects on enhancing apple firmness.

The effects of polyamides on detached organs have been correlated with an inhibition of ethylene biosynthesis (Apelbaum et al., 1981; Even-Chen et al., 1982; Saftner and Baldi, 1990; Toumadje and Richardson, 1988). Calcium has also been reported to inhibit ethylene evolution in 'Golden Delicious' apples (Glenn et al., 1988; Sams and Conway, 1984). In our experiments, there was no effect of polyamides on ethylene production. This difference between our results and those of others may be due to the systems used. We applied polyamides to whole fruit, whereas others used apple disks (Ben-Arie et al., 1982) or protoplasts (Apelbaum et al., 1981). Calcium was found to inhibit ethylene evolution in 'Golden Delicious' but not 'McIntosh' apples. Our Ca treatment was also more effective than polyamides in retarding softening in 'Golden Delicious' but not 'McIntosh'. The inhibition of ethylene production results in a reduced rate of softening during cold storage of 'Golden Delicious' (Halder-Doll and Bangerth, 1987). The increased effectiveness of $\mathrm{Ca}$ in inhibiting softening in 'Golden Delicious' relative to polyamides, thus, may relate to these effects on ethylene evolution.

Analysis of the polyamine levels in the treated fruit revealed several interesting metabolic interactions. Application of SPD led to increased accumulation of PUT, perhaps as a result of 


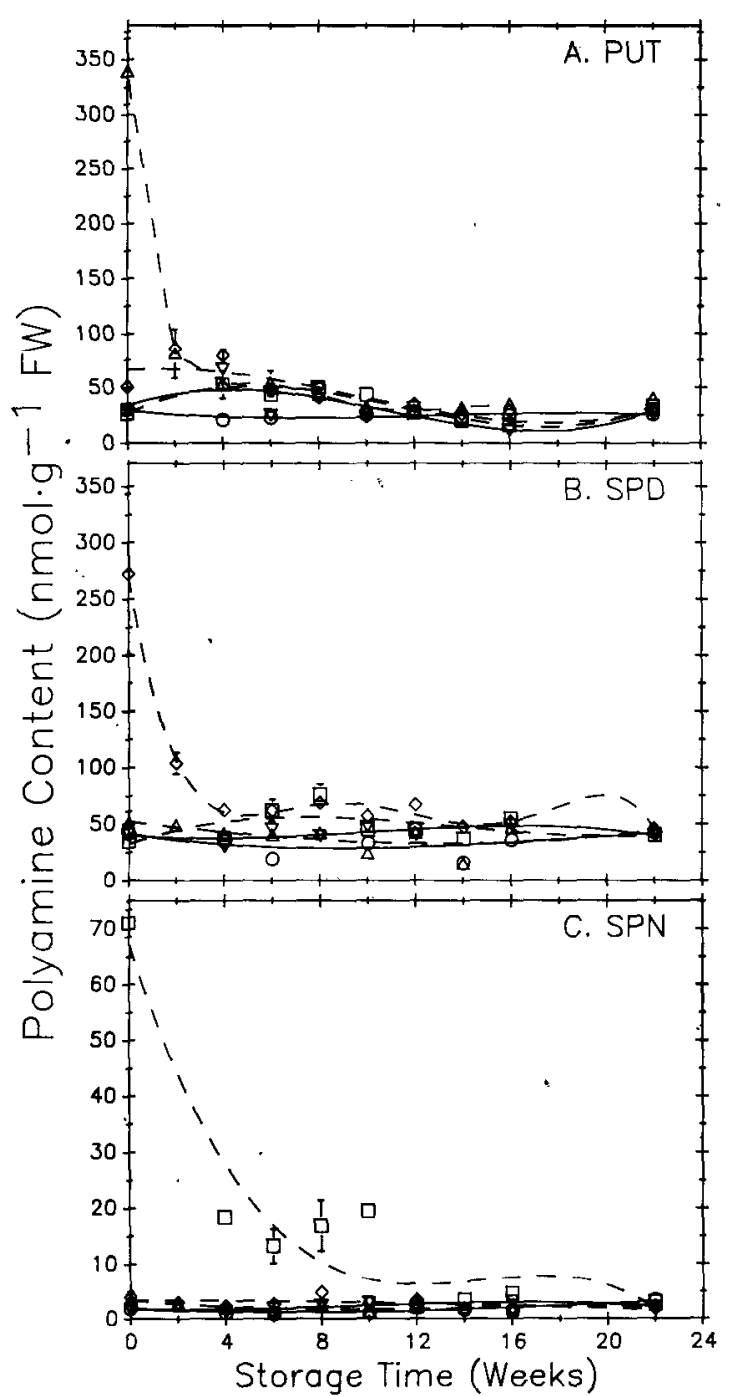

Fig. 3. Effect of pressure infiltration of polyamines on their concentrations in skin of 'Golden Delicious' apples during storage at $0 \mathrm{C}$. Control $\left(0_{-0}\right), 10 \mathrm{mM}$ PUT $(\triangle--\triangle), 1 \mathrm{mM}$ SPD $(\diamond--\diamond), 1 \mathrm{~mm}$ SPN (---口), 3\% Ca $(\nabla-\nabla)$.

inhibition of SPD synthase or promotion of the reverse reaction of this enzyme (SPD to PUT). Similar results have been reported in tobacco plants (Bors et al., 1989). Treatment with SPD also appeared to increase SPN levels, probably a result of conversion of the SPD to SPN via SPN synthase; also, SPN treatment appeared to increase SPD levels. Treatment with $\mathrm{Ca}$ appeared to increase SPD and SPN levels in the flesh. Calcium, thus, may either stimulate synthesis or inhibit degradation of these polyamides. Such an effect could contribute to the inhibition of softening by $\mathrm{Ca}$.

Initially, the levels of the polyamides applied were usually much higher in the skin and flesh than the control, followed by a rapid decline during storage. This decrease in the polyamine levels may result from degradation, conjugation, or transport into the interior of the apple. SPD appeared to be an exception in that the initial levels in the flesh were the same as for the control. The rise of these levels during storage may reflect transport toward the interior. The failure to detect elevated SPD in the flesh initially may indicate that the SPD had not penetrated to the depth at which we sampled $(\approx 2$ to $5 \mathrm{~mm})$. It is also possible that there could have been significant increases in cellwall-bound SPD that were diluted by analysis of the whole cell.

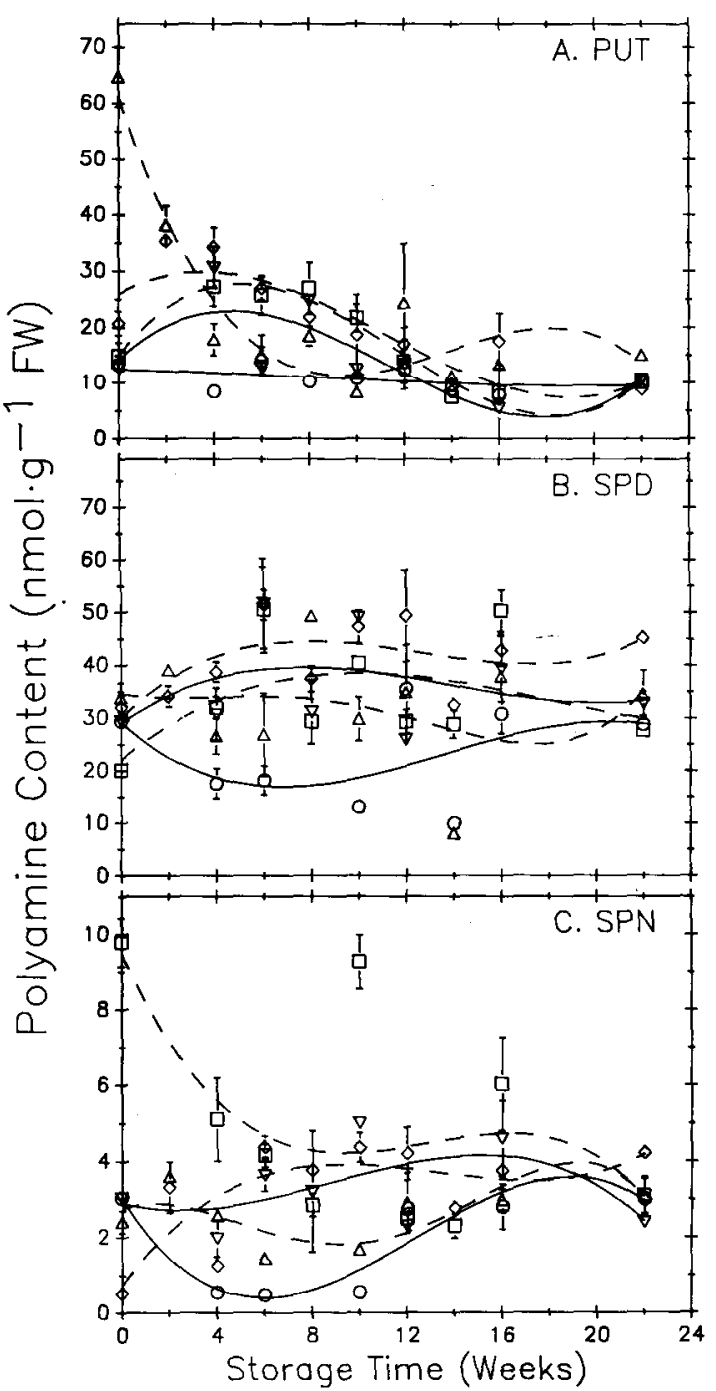

Fig. 4. Effect of pressure infiltration of polyamines on their concentrations in flesh of 'Golden Delicious' apples during storage at $0 \mathrm{C}$. Control $\left(0_{-}\right)$), $10 \mathrm{~mm}$ PUT $(\triangle--\triangle), 1 \mathrm{mM} \operatorname{SPD}(\diamond--\diamond), 1 \mathrm{~mm}$ SPN (ㅁ--- $)$, 3\% Ca $(\nabla-\nabla)$.

Table 2. Effect of 3\% Ca pressure infiltration on Ca levels in the skin (S) and flesh (F) tissue of 'Golden Delicious' and 'McIntosh' apples.

\begin{tabular}{|c|c|c|c|c|c|}
\hline \multirow[b]{2}{*}{ Cultivar } & \multirow[b]{2}{*}{ Treatment } & \multirow[b]{2}{*}{ Tissue } & \multicolumn{3}{|c|}{ Calcium $\left(\mu \mathrm{g} \cdot \mathrm{g}^{-1} \mathrm{dry} w \mathrm{w}\right)$} \\
\hline & & & Content & $(\mathrm{SE})$ & Net increase \\
\hline \multirow{4}{*}{ McIntosh } & Water & $S$ & 539 & (27) & -- \\
\hline & & F & 192 & (19) & --- \\
\hline & $+3 \% \mathrm{Ca}$ & $S$ & 1442 & (257) & 903 \\
\hline & & $\mathrm{F}$ & 378 & (29) & 186 \\
\hline \multirow[t]{4}{*}{ Golden Delicious } & Water & $S$ & 426 & (51) & -- \\
\hline & & $\mathrm{F}$ & 207 & (18) & -- \\
\hline & $+3 \% \mathrm{Ca}$ & $S$ & 1632 & (4) & 1206 \\
\hline & & $F$ & 512 & (17) & 305 \\
\hline
\end{tabular}

Brown core (core flush, CI) is a low-temperature storage disorder that develops in 'McIntosh' apples after several months of storage near 0C (Pierson et al., 1971). Currently, the main method of preventing this disorder is controlled-atmosphere storage at a higher temperature (3C). Calcium has also been shown to inhibit the development of senescent breakdown in 'McIntosh' (Betts and Bramlage, 1977). We have shown here 
that treatment with either polyamine or $\mathrm{Ca}$ is effective in preventing the development of brown core.

The use of polyamides to retard softening in 'Golden Delicious' and 'McIntosh' apples and to prevent brown core in 'McIntosh' could be of commercial importance. Such use would probably be limited to PUT or low concentrations of SPD, as SPN and high levels of SPD cause chemical injury to develop on the skin during storage.

\section{Literature Cited}

Abbott, J. A., W.S. Conway, and C.E. Sams. 1989. Postharvest calcium chloride infiltration affects textural attributes of apples. J. Amer. Soc. Hort. Sci. 114:932-936.

Apelbaum, A., A.C. Burgeon, J.D. Anderson, M. Lieberman, R. BenArie, and A.K. Mattoo, 1981. Polyamides inhibit biosynthesis of ethylene in higher plant tissue and fruit protoplasts. Plant Physiol. $68: 453-456$.

Ben-Arie, R., S. Lurie, and A.K. Mattoo. 1982. Temperature-dependent inhibitory effects of calcium and spermidine on ethylene biosynthesis in apple discs correlate with changes in microsomal membrane microviscosity. Plant Sci. Lett. 24:239-247.

Betts, H.A. and W.J. Bramlage. 1977. Uptake of calcium by apples from postharvest dips in calcium chloride solutions. J. Amer. Soc. Hort. Sci. 102:785-788.

Blanpied, G.D. 1973. Harvesting fresh market apples in New York. Info. Bul. 49. Cornell Univ., Ithaca, N.Y.

Bors, W., C. Langebartels, C. Michel, and H. Sandermann, Jr. 1989. Polyamides as radical scavengers and protestants against ozone damage. Photochemistry 28:1589-1595.

Bramlage, W. J., S.A. Weis, and M. Drake. 1985. Predicting the occurrence of postharvest disorders of 'McIntosh' apples from postharvest mineral analysis. J. Amer. Soc. Hort. Sci. 110:499-502.

Conway, W. S., K.C. Gross, C.D. Boyer, and C.E. Sams. 1988. Inhibition of Penicillium expansum polygalacturonase activity by increased apple cell wall calcium. Phytopathology 78:1052-1055.

Conway, W.S. and C.E. Sams. 1983. Calcium infiltration of golden delicious apples and its effect on decay. Phytopathology 73:10681071.

Conway, W.S. and C.E. Sams. 1987. The effects of postharvest infiltration of calcium, magnesium, or strontium on decay, firmness, respiration, and ethylene production in apples. J. Amer. Soc. Hort Sci. 112:300-303.

Dibble, A. R. G., P.J. Davies, and M.A. Mutschler. 1988. Polyamine content of long-keeping Alcobaca tomato fruit. Plant Physiol. 86:338340 .

D’Orazi, D. and N. Bagni. 1987. In vitro interactions between polyamides and pectic substances. Biochem. Biophys. Res. Comm. 148:1259-1263.

Even-Chen, Z., A.K. Mattoo, and R. Goren. 1982. Inhibition of ethylene biosynthesis by aminoethoxyvinylglycine and by polyamides shunts label from $3,4-\left[{ }^{14} \mathrm{C}\right]$ methionine into spermidine in aged orange peel discs. Plant Physiol. 69:385-388.

Faust, M. and C.B. Shear. 1968. Corking disorders of apples: A physiological and biochemical review. Bet. Rev, 34:441-469.
Glenn, G. M., A.S.N. Reddy, and B.W. Poovaiah. 1988. Effect of calcium on cell wall structure, protein phosphorylation and protein profile in senescing apples. Plant Cell Physiol. 29:565-572.

Halder-Doll, H. and F. Bangerth. 1987. Inhibition of autocatalytic $\mathrm{C}_{2} \mathrm{H}_{2}$-biosynthesis by AVG applications and consequences on the physiological behaviour and quality of apple fruits in cool storage. Scientia Hort. 33:87-96.

Kramer, G.F. and C.Y. Wang. 1989. Correlation of reduced chilling injury and oxidative damage with increased polyamine levels in zucchini squash. Physiol. Plant. 76:479-484.

Kramer, G. F., C.Y. Wang, and W.S. Conway. 1989. Correlation of reduced softening and increased polyamine levels during low-oxygen storage of 'McIntosh' apples. J. Amer. Soc. Hort. Sci. 114:942946.

Laufmann, J. D., C.E. Sams, and W.S. Conway. 1989. Pectin methyl esterase activity in 'Golden Delicious' apples as affected by postharvest calcium treatments. ASHS 1989 Annu. Mtg., Tulsa, Okla., Prog. \& Abstr. p. 59.

Mariani, P., D. D'Orazi, and N. Bagni. 1989. Polyamides in primary walls of carrot cells: Endogenous content and interactions. J. Plant Physiol. 135:508-510.

Pierson, C. F., M.J. Ceponis, and L.P. McColloch. 1971. Market diseases of apples, pears, and quinces. Agr. Hdbk. 376, U.S. Dept. Agr., Washington, D.C.

Pistocchi, R., N. Bagni, and J.A. Creus. 1987. Polyamine uptake in carrot cell cultures. Plant Physiol. 84:374-380.

Saftner, R.A. and B.G. Baldi. 1990. Polyamine levels and tomato fruit development: Possible interaction with ethylene. Plant Physiol. 92:547-550.

Sams, C.E. and W.S. Conway. 1984. Effect of calcium infiltration on ethylene production, respiration rate, soluble polyuronide content, and quality of 'Golden Delicious' apple fruit. J. Amer. Soc. Hort. Sci. 109:53-57.

Smith, M.A. and P.J. Davies. 1985. Separation and quantitation of polyamides in plant tissue by high performance liquid chromatography of their dansyl derivatives. Plant Physiol. 78:89-91.

Stow, J. 1989. The involvement of calcium ions in maintenance of apple fruit tissue structure. J. Expt. Bot. 40:1053-1057.

Suttle, J.C. 1981. Effect of polyamides on ethylene production. Photochemistry 20:1477-1480.

Toumadje, A. and D.G. Richardson. 1988. Endogenous polyamine concentrations during development, storage and ripening of pear fruits. Photochemistry 27:335-338.

Wallace, J., J. Kuc, and H.N. Draudt. 1962. Biochemical changes in the water-insoluble material of maturing apple fruit and their possible relationship to disease resistance. Phytopathology 52:1023-1027.

Wang, C.Y. 1988. Changes in polyamine content in chinese cabbage during storage in air or low oxygen atmosphere. J. Food Quality 11:289-302.

Wang, C.Y. and Z.L. Ji. 1988. Effect of low oxygen storage on chilling injury and polyamides in zucchini squash. Scientia Hort. 39:17.

Wang, C.Y. and G.F. Kramer. 1989. Effect of low-oxygen storage on polyamine levels and senescence in Chinese cabbage, zucchini squash and McIntosh apples, p. 19-27. Fifth Proc. Intl. Controlled Atmosphere Res. Conf. vol. 2. Wenatchee, Wash. 